\title{
Reframing Thinking and Action: A Way Forward in Responding to Child Witch Accusations Through Contextualised Participatory Engagement
}

\author{
Susie Howe and Paul Stockley
}

We welcome this significant contribution to research on the issue of witch accusations against children and the involvement of church leaders. This type of survey of pastors and in depth analysis appears to be unique (we're not aware of any similar research in other localities), and the authors identify the many challenges of getting valid research data. Yet, the lack of research should not be taken to imply a lack of evidence for this phenomenon (of which there is an overwhelming amount), and should not diminish the urgency for action. Nonetheless, the wrong course of action will not help, and may actually hinder, finding solutions.

Robert J. Priest, Abel Ngolo and Timothy Stabell (2020) set before us the challenge: "Where do we go from here?" and they remind us this is not a mere theoretical exercise. In their article they highlight that every day the pastors of EPED ${ }^{1}$ “. . . confront the fact that alleged witches are actual people who suffer actual consequences of being named a witch ... and that when this person is a child, such an accusation raises profound moral, ethical, and practical questions of engagement” (45).

In this response we share our experience of a contextualised, theologically-informed model of engagement which has had a highly positive impact on church leaders. This approach has often led to radical shifts in thinking and action, mobilising many to now champion the cause of protecting children from child witch accusations.

From the outset of our early encounters with this issue in 2012, $\mathrm{SCWA}^{2}$ recognised the importance of engaging with church leaders from across all the church streams, since, as Priest et al. note, "churches today, for good or ill, arguably more than any other social institution, play a central role in influencing people's understandings and ideas about child-witches, and their responses to children perceived to be witches" (9). Working with local NGOs and churches, particularly in the DR Congo and in Togo, this model begins with facilitators running focus groups to explore the underlying root causes, the everyday realities, and the typical responses to the issue of children accused of being witches. While this may seem a very open-ended approach, it was essential to identifying seven significant touch points (or key themes), where people's thinking determines their actions.

We then invited theologians to give insight and enable us to create a guided conversation around each of these touch points, to open up the possibility of alternative ways of thinking and hence of acting. On this basis we initiated action forums, exploring the themes emerging from the research in a guided manner with around forty church pastors and other influential leaders, through a process of theologically-informed reflection and dialogue. From the learning outcomes of these activities, we proceeded to develop a resource for church leaders to use in local workshops. Entitled The Heart of the Matter, this interactive training material fosters cultural critique and affirmative engagement around the seven key themes (as identified and explored earlier), namely: welcoming children as a gift of God; accepting personal responsibility for decisions and actions; understanding child development and trauma; acknowledging God's sovereignty; identifying

' EPED: Équipe Pastorale auprès des Enfants en Détresse, a Congolese NGO based in Kinshasa.

"SCWA: Stop Child Witch Accusations «stop-cwa.org» is a coalition of predominantly Christian agencies and individuals who are responding to this issue. 
the role of pastors; appreciating how the community can help to protect children; and applying the law to advocate for children's welfare. Each topic seeks to address one of the underlying beliefs or root causes of child witch accusations. The Heart of the Matter was successfully piloted in four localities (five local workshops in total) in DR Congo and Togo, before being finalised and made freely available. ${ }^{3}$

Immediate outcomes of the local workshops exceeded expectations. A review of the attendees' questionnaires and personal testimonies evidences a positive change (often to a significant degree) in the understanding of many participants, and their expressed attitudes towards children who may be accused. Initial indications were very encouraging, but we needed to know: Is this a momentary response, or an enduring change? Is it merely an internalised sentiment, or will it lead to wider community impact and outward interventions? Further evaluation is essential to ensuring that the resources provided and interventions initiated actually make a real difference in thinking and actions over the longer term. So one year or more later, we carried out follow-up surveys with the facilitators and participants. These surveys showed that not only was the change in perceptions and understanding lasting, but it had also led to advocacy and practical action by many participants.

In some testimonies we find descriptions of interventions similar to those of the EPED pastors, as outlined in the report by Priest et al., namely: questioning the basis of child witch accusations; addressing the family dynamics (who is accusing whom, and why); looking at other influences (such as poverty); calling out the harm that results to the child; critiquing the logic of suspicion and fear which drives deliverance ministries; sharing newly acquired scriptural insights; and ultimately working to transform the narrative. Some of the local workshop attendees have significantly adapted and reused their new insights and learnings in multiple contexts including: campaigns within the wider community, educating church congregations (their own and neighbouring churches), sharing insights with local neighbours, and seeking reconciliation in their own extended family. Others have since been involved in rescuing and defending children who are accused and abused, and encouraging local authorities to act on children's behalf.

But the change seems to begin with a personal epiphany, as these testimonies ${ }^{4}$ exemplify:
In my personal life, as a result of the . . valuable teaching in the training, I see myself as responsible for the consequences of my own behaviour, and I must not seek someone who is behind my sufferings or a scapegoat, because in the Bible there is no case where a child is accused of being a witch because of someone's misfortunes.

Pastor in Lubumbashi, DR Congo

I noticed a big change in my life. The training I received opened my eyes on many things concerning children. Before, I used to believe that disability and some children's behaviours were linked to curses, or a spell cast on the family, or demon possession. But the module on normal childhood development and the impact of trauma led me to understand that mood changes, sleep difficulties, aggression have nothing to do with the demonic. Since then, my approach when faced with such behaviour in children has changed. I understand them better. I understand the child now and accept them with love, and work with them to change their behaviour. This training was for me a light that illuminated my darkness.

Pastor in Lomé, Togo

This change in understanding and attitude to children then leads to a change in how the church leader responds to children, particularly those who are accused. This is crucial, because of the pastor's influence in the wider community-as Dr. Priest highlights, quoting anthropologist Filip de Boeck who writes, “. . . it is important to note that church leaders themselves are most often not the source of witchcraft allegations against children [but] merely confirm (and thereby legitimize) accusations and suspicions that already exist within the child's family environment" (22).

Again, testimonies from the follow up surveys show that many of those who had attended the local workshops were now responding in a new way, seeking to cause no harm to children who have been accused, and leading to greater harmony in family relationships.

One mother brought her own daughter to me, suspecting that she was a witch, simply because she was having nightmares. When I spoke with the girl, I discovered the nightmares were being caused by the games that were being played by her group of friends. I was able to explain this to the mother. The girl

\footnotetext{
${ }^{3}$ The Heart of the Matter / Le Coeur du Sujet, currently available in English and French, is due to be published in Kiswahili and Lingala in 2020. Online source " stop-cwa.org/search/resources?name=heart ".
}

${ }^{4}$ Note: All excerpts from testimonies of pastors are anonymised, translated from French, originals retained on file. 
stopped playing with this group and the nightmares stopped. The family is now living happily together.

Pastor in Goma, DR Congo

My half-sister has a daughter who is 16 and who was still wetting the bed every night and was doing badly at school. This was all attributed to witchcraft, and she was believed to be under the control of a powerful witch, which was why she was wetting the bed. She was abused and mistreated and traumatised by everyone in the family. . . .I started to teach the family, showing them that what they were doing was all wrong. I explained that wetting the bed could be for many reasons, rather than being linked to witchcraft. I told them about the effects of trauma, or maybe she was simply overwhelmed, or even afraid of waking the others. Eventually they understood, and the girl is living with the family without difficulty. They have stopped mistreating her and she now rarely wets the bed.

Pastor in Goma, DR Congo

Several church leaders have testified to a significant 'reversal' in their approach. They have changed from being accusers to becoming advocates, now standing up and speaking out for children accused of being witches.

In our nation there is a phenomenon called 'kitshundo' which means 'deliverance'. This involves shaking, hitting, shouting, inappropriately touching a man or woman (or child) to 'deliver' him or her from possession of witchcraft. It all starts with either a prophet who influences them, or a sudden change in the behaviour of the child, often because of the way he is being treated by the family and by a refusal to take responsibility. But rather than pile all the blame on the head of the child, I mobilise, raise awareness, and spread the message to church congregations so that they know that this is not right, and how they should act in such circumstances.

Church leader in Goma, DR Congo

While church leader influence has potential to be a major catalyst for change, other sectors of society need to be involved. Municipal authorities (mayors, town or village leaders, magistrates, police) also need to be aligned to support children, deterring those who accuse and abuse, and holding those who do so to account. One example is in Masisi, DR Congo, where recently a group of church leaders, inspired by their new insights, approached the local authorities to ask if they could share their learning with the police, who rarely intervene in cases of child witch accusations and associated violence, and were even known to accuse children of being witches. The local authorities and police have accepted this offer.

These are a selected sample of the outcomes of The Heart of the Matter training resource. Nonetheless, this approach is only reaching a relatively limited number of people in specific localities. Creative initiatives using other media are essential to extend the conversation into a broader society-wide modality. Engagement via $\mathrm{TV}$, film, and radio is needed. Member agencies in the SCWA Coalition have created audio Bible studies and radio resources based on The Heart of the Matter material, to great effect. ${ }^{5}$ These address the same seven key themes in a similar manner, opening up an alternative narrative to these situations, creating possibilities for change.

Changes that we have seen from this approach are not necessarily on the level of deeply held belief as to whether witchcraft exists (or not). Rather change is evident in the belief as to whether this particular child is a witch and responsible for this particular misfortune, and more generally, whether these children are witches and responsible for these misfortunes. Ultimately, regardless of beliefs that are held, the key outcome question is: How are children to be treated?

Further engagement is needed using a diversity of effective modes of reframing thinking and action. We acknowledge the problems identified by Priest et al., especially: a hybrid fusion of scripture and culture; deeply rooted beliefs in mystical powers; and the need to making sense of suffering. We are also sensitive to the need to consider carefully our use of words and terminology, especially being aware of the problematic interplay between scripture and local language meanings. At the level of church leadership, pastors need exposure to these alternative perspectives and skills earlier on, during their theological training. And at the local community level, we are now developing resources focused on parents and the family context.

From our experience, we have learnt the importance of ...

- Working with church leaders; showing respect, humility, and a willingness to listen and learn; using patient and gentle persuasion rather than a confrontational approach.

- Creating space for open, safe, respectful listening and dialogue.

- Carrying out research into the roots, realities, and responses to accusations of witchcraft against children and adults so that effective, holistic responses can be created.

\footnotetext{
${ }^{5}$ Also available at online source: «stop-cwa.org/search/resources?name=heart». Full evaluation of the impact of these resources is in process.
} 
- Using a multi-faceted and holistic approach which includes tackling the underlying issues that may trigger child witch accusations, including poverty.

- Providing research-based, contextualised, theologically under-pinned training resources and practical strategies to help bring about change.

- Forming strategic networks of church leaders with theologians and those from other disciplines, including links with community-based agencies able to influence local values and attitudes.

Finally, we must keep in focus that this is not a mere theoretical exercise about the potential of occult powers to engage human agents, but it is real children who are being tortured, and real families who are being torn apart. Child witch accusations can also paralyse entire communities through fear, suspicion, accusations, and reprisals. When SCWA was founded, we were told it was impossible to influence deeply-entrenched beliefs and practices, and to stop violence against children accused of being witches. However, the authors hope we have shown that through creating opportunities for open dialogue and discourse, and providing practical training resources, significant positive change in individuals, churches, and communities is possible.

Taking a wider global perspective, Priest et al. state that "the seriousness of the issues, and the difficulties they pose for Christians, and the implications of our engagements for the credibility and witness of Christian churches across time and space, would suggest the importance of an Africa-wide and even global Christian conversation among church historians, biblical scholars, theologians, missiologists, and anthropologists over the issues and their implications" (40). We would welcome this, and also respectfully add that such a conversation must lead towards intentional, collaborative, practical interventions at national and local level, for the sake of the countless children and adults who are living as outcasts today because they are accused of being witches.

\section{Bibliography}

Howe, Susie, and Stockley, Paul. 2013 and 2017. A Call to Action: Responding to Beliefs that Harm Children. SCWA Coalition. https://stopcwa.org $/ \mathrm{search} /$ resources?name $=$ call. Accessed Jan 1, 2020 .

Boyd, Seren. 2017. Roots, Realities, and Responses: Lessons Learnt in Tackling Witchcraft Accusations Against Children. London: SCWA Coalition. https://stopcwa.org $/$ search $/$ resources?name $=3$ R. Accessed Jan 1, 2020 .
Priest, Robert, and Ngolo, Abel. 2018 and 2019. The Kinshasa Survey. SCWA Coalition. https://stopcwa.org/search/resources?name=kinshasa. Accessed Jan 1,2020 .

Priest, Robert J., Abel Ngolo and Timothy Stabell. 2020. Christian Pastors and Alleged Child Witches in Kinshasa, DRC. On Knowing Humanity Journal 4(1):1-51.

Southam, Hazel, and Gent, Carolyn. 2018. Getting to the Heart of the Matter. London: SCWA Coalition. https://stop-cwa.org/search/resources?name=heart. Accessed Jan 1, 2020.

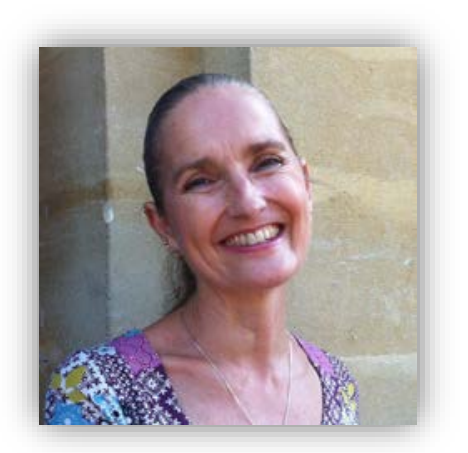

Susie Howe is a founding member of the SCWA Coalition. She is also the Founding Director of The Bethany Children's Trust and for the past 25 years has frequently travelled to nations across the African continent to mobilise and train churches in childcare and protection, and to strengthen project partners. Susie speaks in churches and at events around the UK. Her book about her work with children at risk is Resistance Fighter: God's Heart for the Broken, InterVarsity Press, 2011.

Author email: susieh@bethanychildrenstrust.org.uk

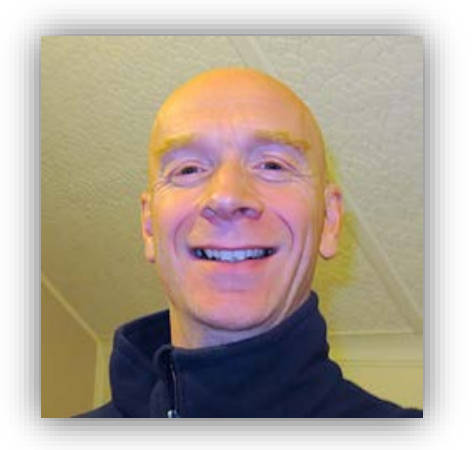

Paul Stockley is a founding member of the SCWA Coalition. He also serves a limited portfolio of charities invested in people working with children in especially challenging circumstances. Primary roles 
include coaching emerging leader-trainers in several localities globally, and developing theologically informed resources for the front-line practitioner. He is co-editor of Understanding God's Heart for Children: Toward a Biblical Framework, Authentic Media, 2007.

Author email: pstocklev@amor.org

The SCWA Coalition "Stop Child Witch Accusations" has been actively functioning as an advocacy and mobilisation group since January 2012, and was formalised in May 2014. We are a coalition of individuals and agencies responding to the reality of children experiencing serious harm or the threat of harm due to accusations of witchcraft or belief in malevolent spiritual influence, and we work with churches and partner agencies on location to engage with the problem of harmful beliefs and practices. 